with loathing and with dread from their useless destruction, and from the very wantonness with which the humblest of God's created things is constantly destroyed.' After a vote of thanks to the worthy President, the Meeting adjourned._Richmond Herald.

The Members of the Malvers Fierd-club held their Annual Meeting for the election of Officers, the audit of accounts, \&c., at the Museum of the Society, at Malvern, on April 5th. The Rev. W. S. Symonds, of Pendock, was re-elected President; Edwin Lees, Esq., Vice-president; and the Rev. R. Pindar Hill, Hon. Secretary. The places of Meeting for the ensuing season are as follows :-May - The Lickey Hills, near Bromsgrove. June-Cleobury-Mortimer. July-Lower Lode, Tewkesbury. September-Birmingham, for the Meeting of the British Association, with a Field-meeting at Malvern after the British Ass ociation Meeting. The Club voted the sum of $£ 10$ to the President and a Committee, for the investigation of certain Drift Deposits in the district; and $\$ 5$ to Mr. Lees for the opening of a tumulus in the neighbourhood of Malvern.-W. S. S.

\title{
CORRESPONDENCE.
}

\section{To the Editor of the Geological Magazine.}

SIR,-With reference to the Article in No.IX. ' On a sudden Sinking of the Soil in a Field at Lexden in Essex,' by the Rev. O. Fisher, I wish to offer a few suggestions. The sinking occurred in 1861; and in 1862 I visited the spot and examined it carefully. It corresponds exactly with Mr. Fisher's description with one exception, which may or may not be of importance in the explanation of the formation of this curious pit. He has omitted to state that on one side of the pit, the earth has not quite subsided on a level with the floor, but rises in a rather abrupt bank. At least it was so when I visited it, which was nearly a year prior to Mr. Fisher's visit; and perhaps during that time alterations might have taken place, or some of the soil been removed. home.

I here give a rough section I made immediately on my return

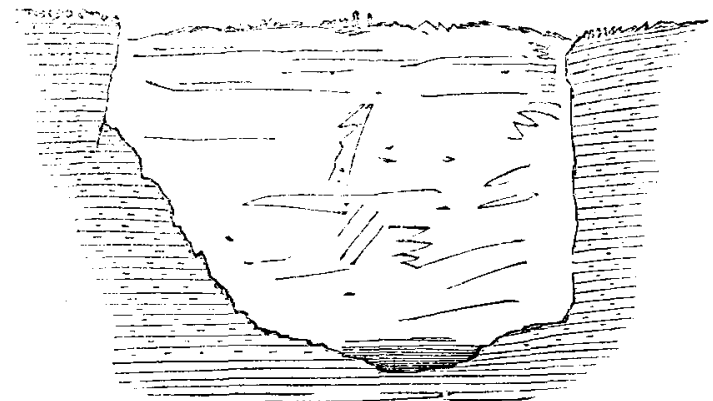

Fig. 1,--Section of the Natural Pit at Lexden, in 1862. 
Mr. Fisher says, "That there must be a vacuity somewhere beneath the subsidence is clear. That it should be in the gravel is impossible, because the stratification, as exposed in the sides of the liole for about 10 feet, is perfectly regular; that it exists in the London Clay is also impossible; but that such a cavity should exist in the Chalk is probable.' Now I would wish to question Mr. Fisher's explanation with all humility, as I am but a rery young hand at Geology.

The author of the article then proceeds to state, that wells have been bored in the neighbourhood, at distances of a mile or more from the pit; and he continues, 'I conceive, then, that the motion of the water in this subterranean reservoir' (in the chalk at a deptl of nearly 300 feet), 'caused by the draught of water at these wells, disturbed the equilibrium of the roofing of the chasm at a point where it was barely stable, and caused the subsidence in question.' I would suggest, if the cavity at this depth were large, why did not a larger area subside? - and, if small, surely it would not cause a roof of from 200 to 300 feet thick to sink. The explanation that I would suggest, would rather be, that erosion has taken place in the Low-level-gravel at a small depth below the pit, say 20 fect or a little more (allowing an inequality in the thickness of the bed of gravel, which at the well a mile distant was found to be about 12 feet), and that, when this erosive action had sufficiently undelmined, the roof fell in.

I might better explain my ideas by the following section (hypothetical).

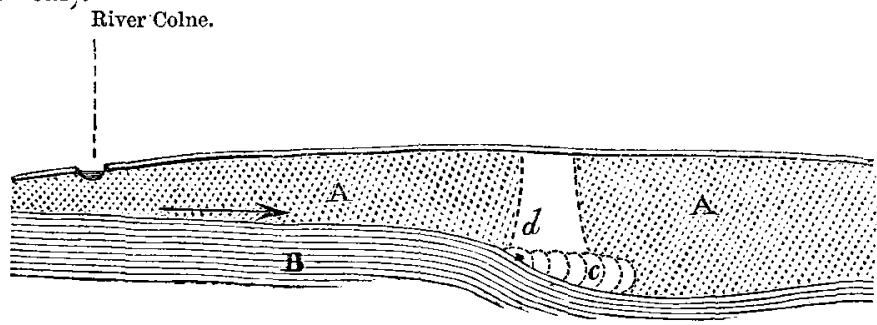

Fig. 2.-Diagram to explain the Formation of the Pit.

A. Low-level-gravel.

c. Dottcd lines to show successive stages of erosion.

B. London Clay.

$d$. Point at which the débris would (and did) stand highest.

The erosion would have been either from water from the River Colne, or from rain having percolated the gravel and run down an inclined surface of the clay at its junction with the gravel.Yours, \&c., Frank Rutley.

13, Denbigh Place, S.W.

THE BURNING WELL AT BROSELEY.

To the Editor of the Geological Magazine.

Sir,-As I did not perceive any reply in the last Number of the Geological Magazine to the enquiry in the previous Number relative to the Burning Well at Broseley, mentioned in some old topo- 